\title{
Pengaruh Motivasi Dan Disiplin Terhadap Kinerja Pegawai Pada Dinas Kependudukan Dan Pencatatan Sipil Kota Tangerang
}

\author{
Akhmar Barsah \\ Dosen Fakultas Ekonomi Universitas Pamulang \\ Email:dosen01578@unpam.ac.id
}

\begin{abstract}
ABSTRAK
Tujuan dari penelitian ini adalah untuk mengetahui pengaruh motivasi kerja dan disiplin kerja terhadap kinerja pegawai pada Dinas Kependudukan dan Pencatatan Sipil Kota Tangerang baik secara parsial maupun simultan.

Metode penelitian yang digunakan dalam penelitian ini adalah metode kuantitatif dengan bentuk asosiatif (kausal) dan pengumpulan data dengan teknik kuesioner. Populasi dalam penelitian ini berjumlah 108 orang dan untuk penetapan sampel menggunakan teknik nonprobability sampling dengan jenis sampel jenuh didapat sampel sejumlah 108 orang. Metode analisis data dengan uji validitas, uji reliabilitas, persamaan regresi linier berganda, korelasi berganda, koefisien determinasi, dan uji signifikansi.

Hasil penelitian menunjukkan korelasi berganda 0.645 artinya motivasi dan disiplin terhadap kinerja pegawai memiliki hubungan kuat. Nilai koefisien determinasi didapat nilai adjusted $R$ square sebesar $40.4 \%$ menunjukkan bahwa besarnya kontribusi dari variabel bebas (motivasi dan disiplin) terhadap kinerja pegawai, sedangkan sisahnya 59.6\% dapat dijelaskan oleh faktor-faktor selain yang diteliti dalam penelitian ini. Secara uji simultan terdapat pengaruh yang signifikan antara motivasi dan disiplin terhadap kinerja pegawai pada Dinas Kependudukan dan Pencatatan Sipil Kota Tangerang, hal ini terlihat dari $F_{\text {hitung }}>$ $F_{\text {tabel }}(37.333>3.08)$. Berdasarkan uji parsial (uji t), variabel motivasi mempunyai nilai sig (0.000) dan t-hitung 5.770, sedangkan disiplin mempunyai nilai sig (0.005) dan t-hitung 2.865, sedangkan dari tabel statistik didapat nilai $\mathrm{t}_{\text {tabel }} 1.98$, artinya baik motivasi dan disiplin secara parsial berpengaruh signifikan terhadap kinerja pegawai di mana $t_{\text {hitung }}>\mathrm{t}_{\text {tabel }}$ dan nilai sig $<0.05$. Dalam persamaan regresi linier berganda di dapat $\mathrm{Y}=10.223+0.492 \mathrm{X}_{1}+0.233 \mathrm{X}_{2}$ yang artinya apabila variable $\mathrm{X}_{1}$ dinaikan 1 satuan, maka variabel $\mathrm{Y}$ naik sebesar 0.492 satuan pada konstanta 10.223 , dan apabila variabel $\mathrm{X}_{2}$ dinaikan 1 satuan, maka variabel Y naik sebesar 0.233 satuan pada konstanta 10.223 .
\end{abstract}

\section{Kata Kunci: Motivasi, Disiplin, Kinerja.}


PENDAHULUAN

\section{Latar Belakang Masalah}

Indonesia adalah bangsa yang besar dengan latar belakang yang sangat majemuk, untuk menata keberagaman SDM yang ada tidaklah mudah terlebih di era globalisasi yang berlaku saat ini. Belakangan ini permasalahan yang ada di Indonesia semakin komplek serta ditambah persaingan global di mana dunia kerja sangatlah membutuhkan orang yang mampu bersaing dan mempunyai keterampilan yang baik serta dapat berifikir maju dan juga mempunyai semangat yang tinggi. Salah satu masalah utama adalah pada tata pemerintahan yang baik di organisasi pemerintah (Good governance). Di dalam suatu organisasi yang melayani publik seperti organisasi dalam pemerintah, keberadaan pegawai merupakan salah satu hal yang amat penting. Dengan adanya pegawai yang mempunyai kualitas akan mempunyai pengaruh dalam mencapai tujuan organisasi. Artinya Sumber daya manusia merupakan salah satu elemen terpenting yang akan menjalankan roda aktivitas organisasi.

Manajemen sumber daya manusia sangat berperan penting untuk mengatur pengelolaan sumber daya manusia dan sumber daya perusahaan atau organisasi, agar dapat memberikan suatu hasil yang maksimal. Manajemen mempunyai arti yang sangat luas, dapat berarti proses, seni, ataupun ilmu. Dikatakan proses karena manajemen terdapat beberapa tahapan untuk mencapai tujuan yaitu perencanaan, pengorganisasian, pengarahan, dan pengawasan. Dikatakan seni karena manajemen suatu cara atau alat untuk seorang manajer dalam mencapai tujuan.

Penulis dalam hal ini melakukan penelitian pada instansi pemerintah di kantor Dinas Kependudukan dan Pencatatan Sipil Kota Tangerang. Dari pengamatan awal yang penulis lakukan ditemukan masalah seperti pegawai tidak melakukan tugasnya dengan target waktu yang telah di rencanakan, kurang mempunyai kesadaran diri untuk melakukan sesuatu dalam melaksanakan tugas dan tanggung jawab. Faktor lain yang menyebabkan menurunnya kinerja pegawai adalah disebabkan kurangnya inisiatif pegawai dalam mengerjakan tugas, dapat dilihat dari adanya pegawai yang masih harus selalu diperintahkan oleh atasan dalam melaksanakan tugas dan tanggung jawabnya. Hal tersebut secara tidak langsung dapat menghambat proses kerja pegawai dan membuat pekerjaan menjadi tidak efisien.

Hal lain yang penulis temukan adalah kurangnya kesadaran akan tugas dan tanggung jawab pegawai Dinas Kependudukan dan Pencatatan Sipil Kota Tangerang. Pegawai harus mempunyai kesadaran atas tanggung jawab dan tugas yang harus dilaksanakan oleh masingmasing individu. Baik buruknya kinerja seseorang ditentukan oleh individu itu sendiri dalam melaksanakan tugas dan tanggung jawabnya dalam melakukan 
segala aktivitasnya sesuai dengan tata aturan, standar, maupun tugas dan tanggung jawab yang menjadi kewajibannya dalam mengerjakan suatu tugas yang sudah menjadi tanggung jawabnya, dimana keberadaannya sebagai pegawai instansi Dinas Kependudukan dan Pencatatan Sipil Kota Tangerang.

Kinerja pegawai yang mengindikasikan penurunan tentu tidak serta merta terjadi begitu saja. Salah satu penyebab yang menyebabkan hal tersebut di instansi Dinas Kependudukan dan Pencatatan Sipil Kota Tangerang adalah terdapatnya masalah kedisiplinan. Masih dijumpai adanya pegawai yang sering datang terlambat mengikuti upacara pagi, adanya pegawai yang bersikap pasif terhadap pekerjaan, adanya pegawai yang tidak tepat waktu dalam menyelesaikan pekerjaannya dan masih ada sebagian pegawai yang meninggalkan tugas pada jam kerja tanpa keterangan. Kurangnya tindakan tegas dari pimpinan terhadap pegawai yang melakukan ketidakdisiplinan seperti halnya peringatan tertulis atau surat peringatan (SP) kepada pegawai akibat disiplin atau kesalahan ringan yang dilakukan, agar memberikan tindakan jera bagi para pegawai tersebut dan dapat mengurangi kesalahan yang dilakukan.

Dari pengamatan yang penulis lakukan di kantor Dinas Kependudukan dan Pencatatan Sipil Kota Tangerang juga masih terdapat masalah motivasi kerja karyawan, di mana sebagian pegawai merasa dirinya kelelahan atau kurang istirahat hal ini mengakibatkan kurang bergairahnya ketika melaksanakan suatu pekerjaan karena kurangnya kebutuhan fisiologis, seperti halnya senam pagi dan donor darah, senam pagi itu di perlukan bagi kesehatan pegawai agar pegawai dapat meningkatkan kekuatan dan ingatan pada otak sekaligus bermanfaat bagi kesehatan mental. Memiliki fisik dan otak yang produktif, akan menghasilkan pegawai dengan hasil kerja yang juga produktif. Sedangkan donor darah adalah sesuatu hal yang sederhana yang bisa dilakukan, tetapi bisa membuat perbedaan besar dalam hidup orang lain. Setiap kantong donor darah yang didonasikan bisa menyelamatkan tiga orang yang membutuhkan. Dengan ikut berpartisipasi dalam kegiatan donor darah, seorang pegawai dapat terhindar dari berbagai macam penyakit, dan dapat lebih sehat secara psikologis. Tuntutan akan pekerjaan dan atasan atau pimpinan adalah sebagian dari berbagai hal yang bisa menyebabkan motivasi seseorang. Begitu juga kebutuhan aktualisasi diri dalam hal pekerjaan setiap pegawai menyebabkan timbulnya rasa bosan atau jenuh dalam situasi tertentu, dengan rasa jenuh tersebut pegawai kurang bergairah dalam melaksakan suatu pekerjaan. Hasilnya, suatu pekerjaan yang dikerjakan tidak terlaksana dengan baik.

Berdasarkan uraian tersebut di atas, pemberian motivasi kerja dan disiplin kerja cenderung mempengaruhi pegawai dalam 
bekerja, sehingga perlu ditinjau jenis motivasi yang bagaimana yang seharusnya diberikan kepada pegawai dan perbaikan apa yang harus ditingkatkan sehingga kedisiplinan kerja dapat meningkat. Dalam hal ini pula yang mendorong penulis untuk meneliti lebih dalam untuk membuktikan bahwa terdapat pengaruh motivasi kerja dan disiplin kerja terhadap kinerja pegawai di instansi Dinas Kependudukan dan Pencatatan Sipil Kota Tangerang.

\section{Perumusan masalah}

Dalam uraian permasalahan yang akan dibahas, penulis dapat merumuskan masalah sebagai berikut:

a. Apakah terdapat pengaruh signifikan antara motivasi kerja terhadap kinerja pegawai pada Dinas Kependudukan dan Pencatatan Sipil Kota Tangerang?

b. Apakah terdapat pengaruh signifikan antara disiplin terhadap kinerja pegawai pada Dinas Kependudukan dan Pencatatan Sipil Kota Tangerang?

c. Apakah terdapat pengaruh signifikan antara motivasi dan disiplin secara simultan terhadap kinerja pegawai pada Dinas Kependudukan dan Pencatatan Sipil Kota Tangerang?

\section{Tujuan Penelitian}

Berdasarkan latar belakang dan rumusan masalah yang ada, maka penelitian ini dilakukan dengan tujuan:

a. Untuk mengetahui apakah terdapat pengaruh signifikan antara motivasi terhadap kinerja pegawai pada Dinas Kependudukan dan Pencatatan Sipil Kota Tangerang.

b. Untuk mengetahui apakah terdapat pengaruh signifikan antara disiplin terhadap kinerja pegawai pada Dinas Kependudukan dan Pencatatan Sipil Kota Tangerang.

c. Untuk mengetahui apakah terdapat pengaruh signifikan antara motivasi dan disiplin secara simultan terhadap kinerja pegawai pada Dinas Kependudukan dan Pencatatan Sipil Kota Tangerang.

\section{TINJAUAN PUSTAKA}

\section{Motivasi Kerja}

Menurut Rivai (2014:607), "Motivasi adalah serangkaian sikap dan nilai-nilai yang memengaruhi individu untuk mencapai hal yang spesifik sesuai dengan tujuan individu". Sedangkan indikator motivasi yang digunakan dalam penelitian ini berdasarkan pendapat Maslow dalam Rivai (2014:609), yaitu sebagai berikut:

a. Kebutuhan fisiologis, antara lain seperti kebutuhan akan sandang, pangan, papan dan kebutuhan jamani lainnya.

b. Kebutuhan keamanan, antara lain kebutuhan akan keselamatan dan perlindungan terhadap kerugian fisik.

c. Kebutuhan social, antara lain hubungan persahabatan, komunikasi, kekeluargaan dan rasa saling memiliki.

d. Kebutuhan penghargaan, antara lain mencakup faktor penghormatan diri seperti 
harga diri, otonomi, prestasi, status di perusahaan, pengakuan dan perhatian.

e. Kebutuhan aktualisasi diri, merupakan dorongan untuk menjadi seseorang yang sesuai dengan ambisinya mencakup pertumbuhan, pencapaian potensi dan pemenuhan kebutuhan diri.

\section{Disiplin}

Menurut Singodimedjo dalam Edy Sutrisno (2016:86), menyatakan bahwa Disiplin adalah "sikap kesediaan dan kerelaan seseorang untuk mematuhi dan menaati normanorma peraturan yang berlaku disekitarnya". Sedangkan indikator disiplin kerja menurut Singodimedjo dalam Edy Sutrisno (2016:94) yang meliputi:

a. Taat terhadap aturan waktu Dilihat dari jam masuk kerja, jam pulang dan jam istirahat yang tepat waktu sesuai dengan aturan yang berlaku di organisasi atau instansi.

b. Taat terhadap peraturan organisasi dan instansi

Peraturan dasar tentang cara berpakaian, dan bertingkah laku dalam pekerjaan.

c. Taat terhadap aturan perilaku dalam pekerjaan

Ditunjukan dengan cara-cara melakukan pekerjaanpekerjaan sesuai dengan jabatan, tugas, dan tanggung jawab serta cara berhubungan dengan unit kerja yang lain.

d. Taat terhadap peraturan lainnya Aturan tentang apa yang boleh dan apa yang tidak boleh dilakukan oleh para pegawai dalam organisasi.

\section{Kinerja}

Menurut Benardin dan Russel (2000) dalam Donni (2014:270), "Kinerja merupakan hasil yang diproduksi oleh fungsi pekerjaan tertentu atau kegiatankegiatan pada pekerjaan tertentu selama periode tertentu". Sedangkan indikator kinerja menurut Mondy, Noe, Premeaux dalam Donni (2014:271) adalah sebagai berikut:

a. Kuantitas Pekerjaan

Kuantitas pekerjaan berhubungan dengan volume pekerjaan dan produktivitas kerja yang dihasilkan oleh pegawai dalam kurun waktu tertentu.

b. Kualitas Pekerjaan

Kualitas pekerjaan berhubungan dengan pertimbangan ketelitian, presisi, kerapian, dan kelengkapan, di dalam menangani tugas-tugas yang ada di dalam organisasi.

c. Kemandirian

Kemandirian berkenaan dengan pertimbangan derajat kemampuan pegawai untuk bekerja dan mengemban tugas secara mandiri dengan meminimalisir bantuan orang lain. Kemandirian juga menggambarkan kedalaman komitmen yang dimiliki oleh pegawai.

d. Inisiatif

Inisiatif berkenaan dengan pertimbangan kemandirian, fleksibilitas berfikir, dan kesediaan untuk menerima tanggung jawab.

e. Adaptabilitas

Adaptabilitas berkenaan dengan kemampuan untuk beradaptasi, 
mempertimbangkan

kemampuan untuk bereaksi terhadap mengubah kebutuhan dan kondisi-kondisi.

\section{Kerangka Berpikir}

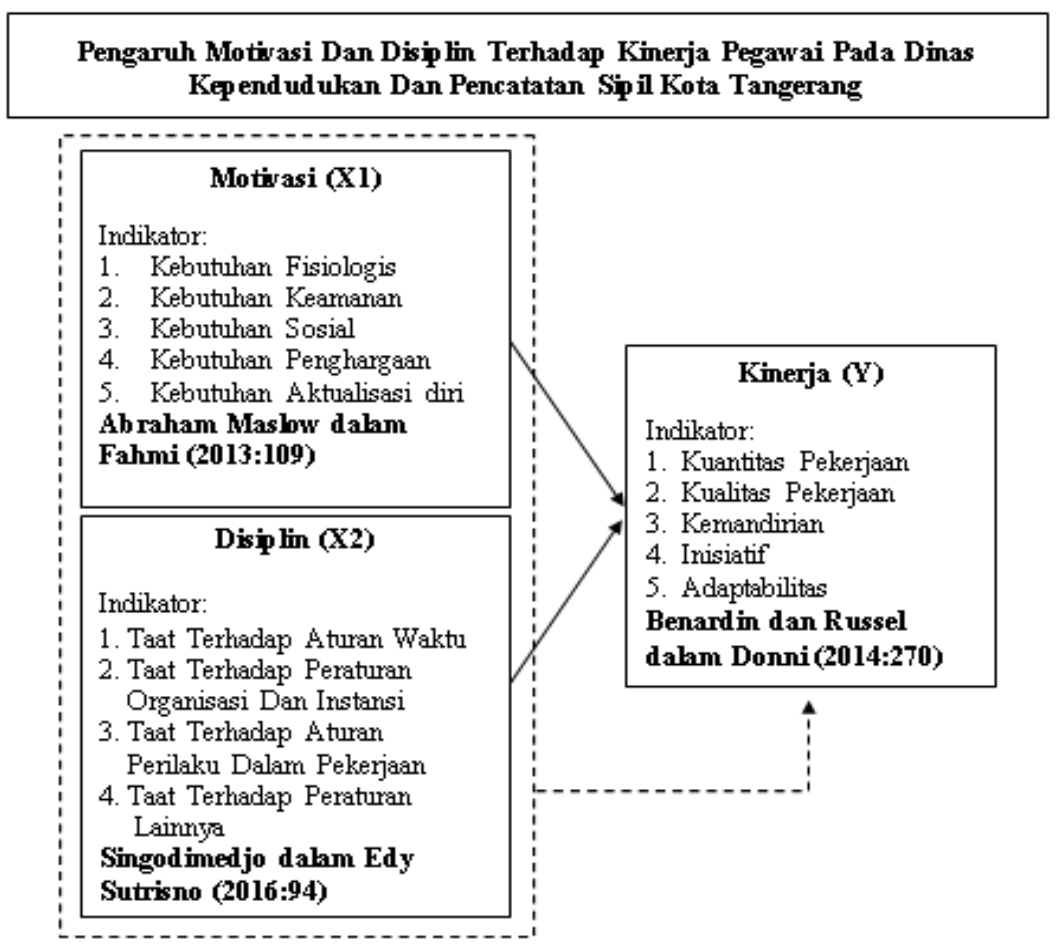

Gambar 2.1 Kerangka Berp ikir

\section{Hipotesis Penelitian}

Menurut

(2011:93), hipotesis adalah jawaban sementara terhadap rumusan masalah penelitian, oleh karena itu rumusan masalah penelitian biasanya disusun dalam bentuk kalimat pertanyaan. Berdasarkan kerangka pemikiran di atas serta untuk menjawab rumusan masalah yang diajukan maka dapat dirumuskan hipotesis penelitian sebagai berikut.

a. Pengaruh Motivasi Terhadap Kinerja.

Ho: Diduga tidak terdapat pengaruh signifikan antara motivasi terhadap kinerja pegawai pada Dinas

Kependudukan dan Pencatatan Sipil Kota Tangerang.

Ha: Diduga terdapat pengaruh signifikan antara motivasi terhadap kinerja peawai pada Dinas Kependudukan dan Pencatatan Sipil Kota Tangerang.

b. Pengaruh Disiplin Terhadap Kinerja

Ho: Diduga tidak terdapat pengaruh signifikan antara disiplin terhadap kinerja pegawai pada Dinas Kependudukan dan Pencatatan Sipil Kota Tangerang. 
Ha: Diduga terdapat pengaruh signifikan antara disiplin terhadap kinerja pegawai pada Dinas Kependudukan dan Pencatatan Sipil Kota Tangerang.

c. Pengaruh Motivasi dan Disiplin Terhadap Kinerja.

Ho: Diduga tidak terdapat pengaruh signifikan antara motivasi dan disiplin kerja secara simultan terhadap kinerja pegawai pada Dinas Kependudukan dan Pencatatan Sipil Kota Tangerang.

Ha: Diduga terdapat pengaruh signifikan antara motivasi dan disiplin kerja secara simultan terhadap kinerja pegawai pada Dinas Kependudukan dan Pencatatan Sipil Kota Tangerang.

\section{METODE PENELITIAN}

\section{Lokasi dan Waktu Penelitian}

Lokasi pelaksanaan penelitian ini adalah pada Dinas Kependudukan dan Pencatatan Sipil Kota Tangerang, Jl Perintis Kemerdekaan, No 1, Babakan, Kota Tangerang, Banten (15117). Sedangkan masa waktu penelitian dilakukan selama 3 (tiga) bulan terhitung mulai Januari 2019 sampai dengan Maret 2019.

\section{Metode Penelitian}

Penelitian ini menggunakan data-data berdasarkan angka yang didapat dari instrumen penelitian yaitu kuesioner yang diolah melalui statistik. Untuk itu penelitian ini menggunakan metode kuantitatif dengan bentuk asosiatif (kausal) yaitu mengukur pengaruh dan nilai variabel independen Motivasi dan Disiplin terhadap variabel dependen Kinerja.

\section{Populasi dan Sampel}

Menurut Sugiyono (2011:80), "Populasi adalah wilayah generalisasi yang terdiri atas: obyek/subyek yang mempunyai kualitas dan karakteristik tertentu yang ditetapkan oleh peneliti untuk dipelajari dan kemudian ditarik kesimpulannya". Adapun jumlah populasi adalah 108 orang. Selanjutnya Sugiyono (2011:81), mengemukakan "Sampel adalah bagian dari jumlah dan karakteristik yang dimiliki oleh populasi tersebut. Teknik pengambilan sampel dalam penelitian ini menggunakan Nonprobability Sampling dengan teknik sampel jenuh. Berdasarkan populasi yang ada maka sampel yang digunakan adalah keseluruhan dari populasi sejumlah 108 orang.

\section{Metode Pengumpulan Data}

Data Primer yang penulis gunakan adalah dengan cara observasi dan kuesioner yang disebarkan. Sedangkan data sekunder yang diperoleh berdasarkan literatur, buku-buku, dan penelitian terdahulu, serta data dari instansi dukcapil tangerang.

\section{Metode Analisis Data}

Agar suatu data yang telah terkumpul dapat bermanfaat, maka perlu dilakukan analisis data. Dalam penelitian ini analisis data yang digunakan adalah uji 
instrumen (uji validitas dan reliabilitas), uji asumsi klasik (normalitas, multikolinearitas, heterokedastisitas), korelasi berganda, koefisien determinasi, uji $\mathrm{F}$, uji $\mathrm{t}$, dan persamaan regresi linier berganda.

\section{PEMBAHASAN DAN HASIL PENELITIAN}

1. Gambaran Umum Dinas Kependudukan dan Pencatatan Sipil Kota Tangerang

a. Sejarah singkat

Dinas Kependudukan dan Pencatatan Sipil Kota Tangerang memiliki catatan sejarah yang tidak sama panjangnya dengan berdirinya kota Tangerang. Berdirinya kota Tangerang pada tanggal 28 Februari 1981 keluar peraturan pemerintah nomor 50 tahun 1981 tentang pembentukan kota Administratif Tangerang. Mengikuti peraturan tersebut, maka dimulai juga pembentukan beberapa instansi pemerintahan yang ada di kota Tangerang, maka kantor catatan sipil kota Tangerang berubah nomenklaktur menjadi Dinas Pendaftaran penduduk yang merupakan penggabungan kantor catatan sipil dengan sub bagian administrasi kependudukan pada bagian tata pemerintahan kota Tangerang.

b. Visi dan Misi

1) Visi Dinas Kependudukan dan Pencatatan Sipil Kota Tangerang "Terwujudnya Pelayanan Administrasi Yang Prima".

2) Misi Dinas Kependudukan dan Pencatatan Sipil Kota Tangerang

a) Meningkatkan profesionalisme sumber daya aparatur

b) Menyediakan sarana dan prasarana pelayanan yang representatif dan memadai.

c) Mewujudkan pengelolaan data dan informasi kependudukan yang akurat dan akuntabel.

d) Meningkatkan Kecepatan dan Ketepatan Pelayanan Administrasi

Kependudukan dan Pencatatan Sipil.

\section{Uji Validitas}

Tabel di bawah ini menunjukkan hasil uji validitas terhadap variabel-variabel penelitian yaitu motivasi (X1), disiplin (X2) dan Kinerja (Y) dengan 108 sampel responden.

Tabel 4.1 Rangkuman Hasil Uji Validitas

\begin{tabular}{|c|c|c|c|c|}
\hline Variabel & Pertanyaan & Nilai rhitung & Nilai rtabel & Kriteria \\
\hline Motivasi & Item 1 & 0.557 & 0.1891 & Valid \\
\cline { 2 - 5 } & Item 2 & 0.561 & 0.1891 & Valid \\
\cline { 2 - 5 } & Item 3 & 0.583 & 0.1891 & Valid \\
\cline { 2 - 5 } & Item 4 & 0.637 & 0.1891 & Valid \\
\cline { 2 - 5 } & Item 5 & 0.430 & 0.1891 & Valid \\
\cline { 2 - 5 } & Item 6 & 0.466 & 0.1891 & Valid \\
\hline
\end{tabular}




\begin{tabular}{|c|c|c|c|c|}
\hline \multirow{1}{*}{} & Item 7 & 0.584 & 0.1891 & Valid \\
\cline { 2 - 5 } & Item 8 & 0.407 & 0.1891 & Valid \\
\cline { 2 - 5 } & Item 9 & 0.504 & 0.1891 & Valid \\
\cline { 2 - 5 } & Item 10 & 0.456 & 0.1891 & Valid \\
\hline Disiplin & Item 1 & 0.437 & 0.1891 & Valid \\
\cline { 2 - 5 } & Item 2 & 0.594 & 0.1891 & Valid \\
\cline { 2 - 5 } & Item 3 & 0.558 & 0.1891 & Valid \\
\cline { 2 - 5 } & Item 4 & 0.548 & 0.1891 & Valid \\
\cline { 2 - 5 } & Item 5 & 0.579 & 0.1891 & Valid \\
\cline { 2 - 5 } & Item 6 & 0.475 & 0.1891 & Valid \\
\cline { 2 - 5 } & Item 7 & 0.616 & 0.1891 & Valid \\
\cline { 2 - 5 } & Item 8 & 0.477 & 0.1891 & Valid \\
\cline { 2 - 5 } & Item 9 & 0.524 & 0.1891 & Valid \\
\cline { 2 - 5 } & Item 10 & 0.527 & 0.1891 & Valid \\
\hline Kinerja & Item 1 & 0.463 & 0.1891 & Valid \\
\cline { 2 - 5 } & Item 2 & 0.551 & 0.1891 & Valid \\
\cline { 2 - 5 } & Item 3 & 0.546 & 0.1891 & Valid \\
\cline { 2 - 5 } & Item 4 & 0.602 & 0.1891 & Valid \\
\cline { 2 - 5 } & Item 5 & 0.489 & 0.1891 & Valid \\
\cline { 2 - 5 } & Item 6 & 0.589 & 0.1891 & Valid \\
\cline { 2 - 5 } & Item 7 & 0.458 & 0.1891 & Valid \\
\cline { 2 - 5 } & Item 8 & 0.463 & 0.1891 & Valid \\
\cline { 2 - 5 } & Item 9 & 0.529 & 0.1891 & Valid \\
\cline { 2 - 5 } & Item 10 & 0.606 & 0.1891 & Valid \\
\hline
\end{tabular}

Sumber: data primer yang diolah dengan SPSS versi 24

Dari ke-30 butir pernyataan untuk semua variable penelitian didapat nilai Correlated ItemTotal Correlation di atas nilai $r_{\text {tabel }}$ yang didapat dari df (N-2) 108-2= 01891. Artinya keseluruhan item instrumen variabel dalam penelitian ini adalah valid.

\section{Uji Reliabilitas}

Tabel 4.2 Rangkuman Uji Reliabilitas Data

\begin{tabular}{|c|c|c|}
\hline Variabel & $\begin{array}{c}\text { Cronbach's } \\
\text { Alpha }\end{array}$ & $\begin{array}{c}\text { Kategori Interval } \\
\text { Reliabilitas }\end{array}$ \\
\hline Motivasi Kerja & 0.694 & Reliabel \\
\hline Disiplin Kerja & 0.725 & Reliabel \\
\hline Kinerja Karyawan & 0.709 & Reliabel \\
\hline
\end{tabular}

Sumber data diolah dengan SPSS versi 24

Hasil nilai reliabilitas pada tabel di atas, memberikan arti bahwa variabel Motivasi $\left(\mathrm{X}_{1}\right)$, Disiplin $\left(\mathrm{X}_{2}\right)$ dan Kinerja (Y) yang diperoleh melalui penyebaran kuesioner dikatakan reliable atau dapat dipercaya. Hal tersebut dapat dilihat dari keseluruhan variable penelitian mempunyai nilai Crobach's Alpha $>0.60$.

4. Uji Asumsi Klasik

a. Uji Normalitas

1) Pendekatan Histogram 


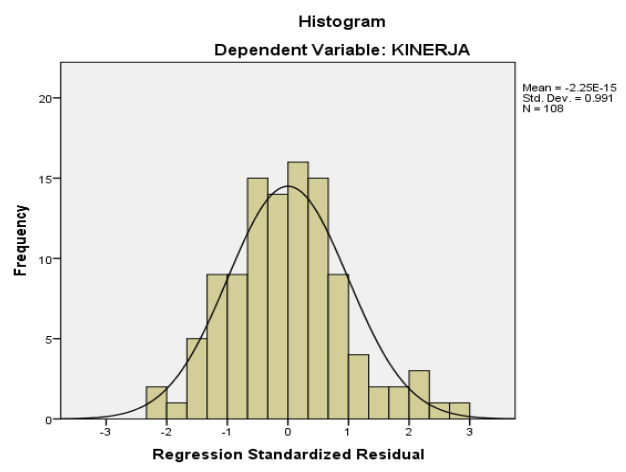

Gambar 4.1 Histogram Uji Normalitas

Dapat diketahui dari hasil uji normalitas dengan pendekatan histogram bahwa data berdistribusi normal, hal ini ditunjukkan oleh distribusi data yang berbentuk lonceng dan tidak melenceng ke kiri atau ke kanan.

2) Pendekatan Grafik P-P Plot

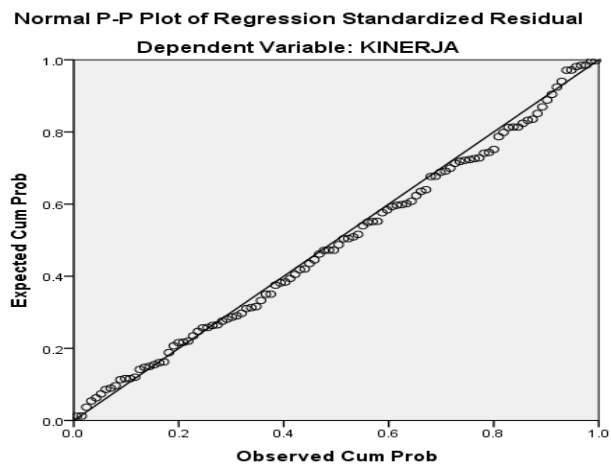

Gambar 4.2 P-P Plot Uji Normalitas

Hasil statistik menunjukkan bahwa pada P-P Plot terlihat titik yang mengikuti data di sepanjang

b. Uji Multikolinearitas

\begin{tabular}{|c|c|c|}
\hline \multirow[b]{2}{*}{ Model } & \multicolumn{2}{|c|}{$\begin{array}{c}\text { Tabel 4.3 Uji Nilai Tolerance dan VIF } \\
\text { Coefficients } \\
\text { Collinearity Statistics }\end{array}$} \\
\hline & Tolerance & VIF \\
\hline \multicolumn{3}{|l|}{1 (Constant) } \\
\hline MOTIVASI & .769 & 1.301 \\
\hline DISIPLIN & .769 & 1.301 \\
\hline
\end{tabular}

garis diagonal. Hal ini menunjukkan bahwa residual normal.
Pada tabel 3. Terlihat

bahwa nilai tolerance semua variabel bebas (motivasi kerja dan disiplin) adalah lebih besar dari nilai ketetapan 0.1 dan nilai VIF semua variabel 
c. Uji Heteroskedastisitas

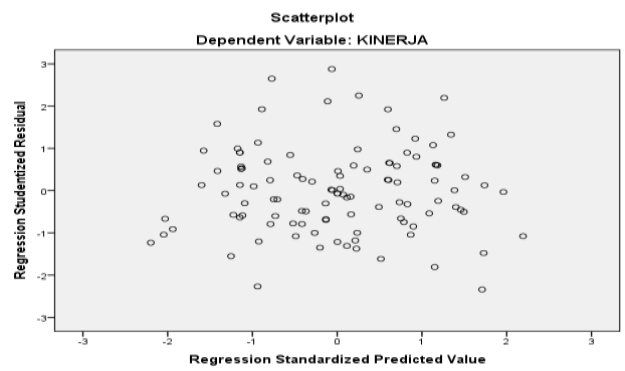

Gambar 4.3. Scatterplot Heteroskedastisitas

Berdasarkan Gambar 3. Dapat terlihat bahwa tidak ada pola yang jelas serta titik-titik menyebar di atas dan di bawah angka 0 pada sumbu $\mathrm{Y}$, maka dapat disimpulkan tidak terjadi heteroskedastisitas.

\section{Pengujian Hipotesis}

\section{a. Korelasi Berganda}

Tabel 4.4. Hasil Pengujian Koefisien Korelasi Model Summary ${ }^{\text {b }}$

\begin{tabular}{lr|r|rr} 
Model & $R$ & R Square & Adjusted R Square & Std. Error of the Estimate \\
\hline 1 & $.645^{\mathrm{a}}$ & .416 & .404 & 3.56251 \\
\hline a. Predictors: (Constant), DISIPLIN, MOTIVASI \\
b. Dependent Variable: KINERJA
\end{tabular}

Berdasarkan hasil uji statistik yang ditunjukkan pada kolom kedua $(\mathrm{R})$ didapat nilai 0.645 yang dapat diartikan bahwa nilai hubungan motivasi dan disiplin dengan kinerja sebesar 0.645 dan bernilai positif. Artinya variable motivasi dan disiplin mempunyai pengaruh terhadap kinerja masuk dalam kategori KUAT (0.60 - 0.799).

\section{b. Koefesien Determinasi}

Berdasarkan table 4 dapat diketahui nilai Adjusted $R$ Square 0.404 atau $40.4 \%$ artinya kinerja pegawai Dinas Kependudukan dan Pencatatan Sipil Kota Tangerang dapat di jelaskan oleh variable motivasi dan disiplin sebesar $40.4 \%$ sedangkan sisahnya $59.6 \%$ adalah faktor-faktor yang tidak diteliti.

\section{c. Uji Simultan (Uji F)}

Tabel 4.5. Hasil Uji Simultan (UJI-F)

\begin{tabular}{|c|c|c|c|c|c|c|}
\hline \multicolumn{7}{|c|}{ ANOVA $^{a}$} \\
\hline & Model & $\begin{array}{l}\text { Sum of } \\
\text { Squares }\end{array}$ & $\mathrm{df}$ & $\begin{array}{l}\text { Mean } \\
\text { Square }\end{array}$ & $\mathrm{F}$ & Sig. \\
\hline \multirow[t]{3}{*}{1} & Regression & 947.613 & 2 & 473.806 & 37.333 & $.000^{\circ}$ \\
\hline & Residual & 1332.605 & 105 & 12.691 & & \\
\hline & Total & 2280.218 & 107 & & & \\
\hline
\end{tabular}

b. Predictors: (Constant), DISIPLIN, MOTIVASI

Tabel 5 di atas Sedangkan F-tabel pada tingkat mengungkapkan bahwa nilai F- kepercayaan 95\% $(\alpha=0.05)$ hitung adalah 37.333 dengan adalah 3.08. Oleh karena itu tingkat signifikansi 0.000 pada kedua perhitungan yaitu 
F-hitung > F-tabel dan tingkat signifikansi $(0.000)<0.05$ menunjukan bahwa motivasi dan disiplin berpengaruh signifikan terhadap kinerja, yang artinya Ho ditolak dan $\mathrm{Ha}$ diterima.

\section{d. Uji Signifikansi Parsial (Uji-t)}

\section{Tabel 4.6. Uji Parsial (Uji t)}

Coefficients $^{\mathrm{a}}$

\begin{tabular}{|c|c|c|c|c|c|}
\hline & \multicolumn{2}{|c|}{ Unstandardized Coefficients } & \multirow{2}{*}{$\begin{array}{c}\text { Standardized Coefficients } \\
\text { Beta }\end{array}$} & \multirow[b]{2}{*}{$\mathrm{T}$} & \multirow[b]{2}{*}{ Sig. } \\
\hline Model & B & Std. Error & & & \\
\hline 1 (Constant) & 10.223 & 2.916 & & 3.505 & .001 \\
\hline MOTIVASI & .492 & .085 & .491 & 5.770 & .000 \\
\hline DISIPLIN & .233 & .081 & .244 & 2.865 & .005 \\
\hline
\end{tabular}

mempunyai nilai sig (0.000) dan t-hitung 5.770, sedangkan disiplin mempunyai nilai sig (0.005) dan t-hitung 2.865, sedangkan berdasarkan tabel statistik didapat nilai t tabel $(\mathrm{N}$ K) $108-3=1.98$ artinya baik motivasi dan disiplin secara parsial berpengaruh signifikan terhadap kinerja di mana $t$ hitung > t tabel dan nilai sig < 0.05. Dapat disimpulkan bahwa untuk pengujian hipotesis pertama dan kedua dalam penelitian ini terbukti signifikan di mana Ho ditolak dan Ha diterima.

\section{e. Persamaan Analisis Regresi} Linear Berganda

Berdasarkan pengujian menggunakan SPSS 24, maka hasil persamaan regresi linear berganda dapat dilihat pada ouput tabel 6 kolom kedua (unstandardized Coefficients) bagian $\mathrm{B}$ diperoleh nilai $\mathrm{b}_{1}$ variabel motivasi sebesar 0.492 nilai $b_{2}$ variabel disiplin sebesar 0.233 dan nilai konstanta (a) adalah 10.223 maka diperoleh persamaan regresi linier berganda $\mathbf{Y}=$ $10.223+0.492 X_{1}+0.233 X_{2}$. ini menunjukkan bahwa jika variabel motivasi dan disiplin dianggap konstan maka variabel kinerja akan bernilai 10.223. Koefisien $\beta 1$ (X1) = 0.492 menunjukkan bahwa jika motivasi meningkat satu-satuan maka kinerja akan naik dengan syarat variabel lain nilainya tetap. Koefisien $\beta 2$ (X2) = 0.233 menunjukkan bahwa jika variabel disiplin semakin baik maka kinerja akan meningkat sebesar 0.233 dengan syarat variabel lain tetap.

\section{KESIMPULAN DAN SARAN}

\section{Kesimpulan}

Berdasarkan hasil analisis dan pembahasan yang telah dilakukan dalam penelitian ini, maka diambil kesimpulan sebagai berikut:

a. Variabel motivasi berpengaruh secara positif dan signifikan terhadap kinerja, hal ini terlihat dari nilai signifikan (0.000) lebih besar dari 0.05 dan thitung (7.888) lebih besar dibandingkan t-tabel (1.98), artinya penurunan kinerja pada pegawai Dinas Kependudukan dan Pencatatan Sipil Kota 
Tangerang dapat dipengaruhi oleh meningkatnya motivasi pada pegawai.

b. Variabel disiplin berpengaruh secara positif dan signifikan terhadap kinerja pegawai, Hal ini terlihat dari nilai signifikan (0.000) lebih kecil dari 0.05 dan t-hitung (5.631) lebih besar dibandingkan t-tabel (1.98). Artinya peningkatan kinerja pegawai pada Dinas Kependudukan dan Pencatatan Sipil Kota Tangerang dipengaruhi oleh disiplin yang baik.

c. Motivasi dan disiplin secara serempak berpengaruh signifikan terhadap kinerja pegawai Dinas Kependudukan dan Pencatatan Sipil Kota Tangerang. Hal ini dapat dilihat dari nilai Sig lebih kecil dari taraf kesalahan $0.05(0.000$ $<0.05)$ dan nilai $F_{\text {hitung }}>F_{\text {tabel }}$ $(37.333>3.08)$. Untuk kontribusi variable bebas terhadap terikat didapat nilai Adjusted $R$ Square sebesar 0.404 berarti $40.4 \%$ artinya kontribusi variabel - variabel bebas mempunyai sumbangsih terhadap variabel terikat sebesar $40.4 \%$ dan sisanya $59.6 \%$ adalah faktor-faktor lain yang tidak diteliti. Berdasarkan perhitungan koefisien korelasi menunjukkan bahwa hubungan antara variabel motivasi dan variabel disiplin memiliki hubungan yang erat terhadap kinerja pegawai Dinas Kependudukan dan Pencatatan Sipil Kota Tangerang. Dengan nilai koefisien korelasi 0.645 yang masuk pada kriteria KUAT (0.60 - 0.799).

\section{Saran}

Berdasarkan hasil pembahasan dan hasil penelitian maka penulis dapat memberikan saran sebagai berikut:

\section{a. Variabel Motivasi}

Dalam segi motivasi, seharusnya para atasan pada Dinas Kependudukan dan Pencatatan Sipil Kota Tangerang bisa melihat kinerja para pegawainya dalam melaksanakan tugasnya, seperti dilihat dari hasil pernyataan kuesioner yang diberikan masih banyaknya atasan yang tidak memberikan penghargaan kepada para pegawainya yang sudah bekerja secara efektif, bahkan jika pegawai telah menjalankan tugasnya dengan hasil yang memuaskan para atasan tidak memberikan pujian kepada bawahannya, ada juga yang beranggapan bekerja di instansi tersebut tidak menjamin kehidupan para pegawainya di hari tua yang mana seharusnya bekerja itu bisa membuat seseorang merasa lebih terjamin di hari tuanya nanti.

\section{b. Variabel Disiplin}

Pegawai harus bisa
memanfaatkan waktu untuk
melaksanakan tugas atau
pekerjaannya dengan cara
efektif dan tidak membuang-
buang waktu agar pekerjaan
yang dikerjakan dan tidak
menumpuk. Hal itu belum
sepenuhnya di terapkan pada
pegawai Dinas Kependudukan
dan Pencatatan Sipil Kota


Tangerang karena kurangnya tindakan tegas yang di berikan atasan kepada bawahannya. Masih banyak juga pegawai yang hadir di kantor lebih dari jam masuk yang telah di tentukan seperti hadir 15 menit sebelum jam kerja, adanya pegawai yang tidak mengikuti apel pagi, ini terjadi karena tidak adanya sanksi tegas yang diberikan atasan kepada bawahannya yang mana seharusnya jika terdapat pegawai yang melanggar jam masuk kerja diberikan sanksi yang tegas agar meningkatkan sikap disiplin para pegawai.

c. Variabel Kinerja

Untuk meningkatkan kinerja para pegawainya, pimpinan Dinas Kependudukan dan Pencatatan Sipil Kota Tangerang harus dapat memberikan apresiasi kepada pegawai yang menyelesaikan tugasnya dengan hasil yang baik. Pegawai juga harus diberikan target dalam melaksanakan pekerjaannya agar pekerjaan atau tugas yag diberikan dapat selesai dengan cepat dan tepat waktu, pegawai lebih diarahkan bagaimana cara memilah pekerjaan yang harus lebih dulu di kerjakan agar pekerjaan tersebut selesai pada waktu yang sudah ditentukan.

\section{DAFTAR PUSTAKA}

Fajar, S. A., \& Heru, T. (2013). Manajemen Sumber Daya Manusia. Yogyakarta: YKPN.
Hasibuan, M. S. (2013). Manajemen sumber Daya Manusia Edisi Revisi. Jakarta: Bumi Aksara.

Priansa, D. J. (2014). Perencanaan dan Pengembangan Sumber Daya Manusia. Bandung: Alfabeta.

Rivai, V. (2014). Manajemen Sumber Daya Manusia Untuk Perusahaan: Dari Teori Ke Praktik. Jakarta: PT RajaGrafindo Persada.

Rusilowati, U. (2013). Manajemen Pengetahuan Berbasis Teknologi Informasi Dalam Konteks Pembelajaran Organisasi. Tangerang Selatan: Asmoro Mediatama.

Sinambela, L. P. (2016). Manajemen Sumber Daya Manusia: Membangun Tim Kerja Yang Solid Untuk Meningkatkan Kinerja. Jakarta: PT Bumi Aksara.

Sugiyono. (2011). Metode Penelitian Kuantitatif, Kualitatif, Dan $R \& D$. Bandung: Alfabeta.

Sugiyono. (2017). Statistika Untuk Penelitian. Bandung: Alfabeta.

Sujarweni, W. (2014). SPSS Untuk Penelitian. Yogyakarta: Pustaka Baru Press.

Sunarsi, D. (2018). Pengaruh Motivasi Dan Disiplin Terhadap Produktivitas Kerja Karyawan Pada PT. Nadi Suwarna Bumi. Jurnal Semarak, 1(1).

Sunarsi, D. (2018). Pengaruh Gaya Kepemimpinan, Motivasi Dan Disiplin Kerja Terhadap Kinerja Pendidik Yayasan Marvin. Inovasi, 5(1), 1-18. 
Sutrisno, E. (2012). Manajemen Sumber Daya Manusia. Jakarta: Kencana.
Unaradjan, D. D. (2013). Metode Penelitian Kuantitatif. Jakarta: Universitas Atma Jaya. 